\title{
The Reigning Princes of Galilee
}

$\mathrm{O}^{\mathrm{P}}$

the various states constituted by the crusaders in Syria at the end of the eleventh century the kingdom of Jerusalem comprised all the conquests gouth of the river Adonis (Nahr Mrahim), and was divided into four greater and a fluctuating number of smaller baronies. Of the former Jaffa and Sidon were on the coast, while that of Montreal, in the Oultrejourdain, and Galilee guarded the inland frontier towards Arabia and Damascus respectively. Jaffa was often held by the king, and before the disruption of the kingdom at Hattin was regarded as the proper fief for the heir apparent or presumptive of the crown. Bidon enjoyed the continuous succession of a single dynasty, while Oultrejourdain and Galilee were ruled by some of the most celebrated fighting men among the Latins. In attempting to enumerate the princes of Galilee and their families the historian is to a certain extent hampered by the fact that the 'Lignages d'Outremer', which may perhaps be called the 'Burke ' of the Latin kingdom, is at fault in ite record of Galileo. The acoount can be supplemented from charters, from the records of other families, and from modern research, but still it can never be as ample and detailed as could be wished.

The prinoipality was first given to Tanored towards the end of 1099 , but it is difficult to establish the exact date when he became prince. He may have raided Tiberias and taken it during the period botween the surrender of Nablus, about $27 \mathrm{July}^{1}$ and his arrival at Ramleh on 7 August; ${ }^{2}$ or ho may bave conquered his fief at the end of August, when there was a large assembly of orusaders at Cayphas (Haifa). ${ }^{3}$ It is improbable that the conquest could have taken place between 15 October and 15 December 1099, as the whole strength of the Latins was then occupied in the siege of Arsuf. At any rate, when Bohemond and Baldwin du Bourg left Jericho on 5 January 1100 , they returned north by way of Tiberias, which would have been unlikely had it still been a hostile city. 6 In May 1100 Tancred was well enough established in his now dominions to be able to leave them in order to join with his overlord, Godfrey de Bouillon, in the successful raid

1 Hegenmeger, Chronologie du Royawme de Jtrualem, 410.

Ibid 417.

Ibid. 497.

- Ibid. 431, 435.

Ibid. 42. 
against Damascus. He returned before the end of the month, but hurried to Jaffa on hearing of Godfrey's illness.? He left Jaffa on 17 July in joint command, with the Patriarch Daimbert, of the army against Acre, ${ }^{8}$ but on hearing of Godfrey's death he besieged Cayphas instead.'

Godfrey had promised the lordship of Cayphas, so soon as that town should be taken, to one of his own knights, Waldemar Carpinel. ${ }^{10}$ On Godfrey's death, however, Tancred, who was disappointed in not being chosen as his successor, seems to have had the idea of forming a large and independent dominion for himself at the expense of the crown. In pursuit of this, being supported by the patriarch, ${ }^{11}$ he seized Cayphas on its surrender, ${ }^{12}$ and added the territory to his fief of Galilee. He even tried to seize Jerusalem itself by a coup de main, but Baldwin, the kingelect, who was coming south ${ }^{13}$ to take up the government, got wind of his intentions and hurriedly sent Hugh of Falkenberg and Robert, bishop of Ramleh, ${ }^{14}$ to hold it against Tancred, who had already attacked the city, but failed, on 25 October 1100.15 Tanored thereupon went to Jaffa, but had no greater success there. ${ }^{10}$ Waldemar sued for his promised fief before the high court at the session held from December 1100 to January 1101, and won his oase. ${ }^{17}$ The new king's tact prevented an actual outbreak of hostilities, and after two interviews, one at the ford over the Nahr el Audje near Jaffa, on 22 February $1101,{ }^{18}$ the other at Cayphas, on 8 March following, persuaded Tancred to accept the ruling of the high court and surrender Cayphas to Waldemar Carpinel. ${ }^{19}$

Tancred also took advantage of the offer of the regency of Antioch, which had been made to him, to hand over Galilee to the king on the condition of being allowed to resume that fief after an interval of at least fifteen months. He then proceded ${ }^{20}$ to administer Antioch during the captivity of his uncle, Bohemond I, who had been taken prisoner together with Tancred's nephew,

- Hagenmeyer, Chronologie du Royaume de Jérusalem, 439.

I Ibid. 469.

- Ibid. 481.

- Ibid. 488.

10 Albert of Aix, Historia, Fi. 27, in Migne, clrvi.

$"$ Hagenmeger, Chron 481.

1) The siege began on $25 \mathrm{July}$, and the town was taken on 20 Augugt 1100 : ibid. $489,486$.

13 Ibid. 303 .

16 Ibid. 511.

"Ibid. 512.

11 Ibid. 628 .

13 Ibid. 500 .

1\% Ibic. 634 .

1v Ibid. 540. Waldemar Carpinel, who had been lord of St. Abraham before be was seisod of Cayphas (Röhricht, Geschichse des Bonigreichs Jeruoalem, 57), was killod in the battle between Ramleb and Ascalon, 7 September, and wo buried in the church of the Holy Sepulchre, 16 September. He is reported to have appeared in a vision to Hugh, archbishop of Lyons, next night (Hegenmeyer, Chromologie ds Royaume de Jerwacem, 618). It seems that he was succeded in Cayphas by Rohart, who was also lord of St. Abraham (Ducange-Rey).

- Hagenmeyer, Chron. 342. 
Richard of Principato, on 15 August 1100, near Melitene, by Gumushtakin ibn Danishmend. ${ }^{21}$ The kingdom was thus rid of its most dangerous vassal. But it was only for a short time, for when the Patriarch Daimbert, who had been Tancred's guest at Antioch since March ${ }^{23} 1102$, went south in the September of that year to reclaim his (from which he had been absent, under a cloud, since 20 September $1101^{23}$ ), he was accompanied by Baldwin du Bourg and Tancred. They arrived at Arsuf on 25 September, and after an unsuccessful expedition against Ascalon went to Jaffa. Here, on 4 October, the king recognized Daimbert as patriarch subject to the final decision of the papal legate, Cardinal Robert. Four days later, however, that decision was given at a council held at Jerusalem, and Daimbert was deposed from his charge. ${ }^{24}$ He died on 16 June 1107.25 After this blow to his policy Tancred returned north.

On 9 March 1101 the king invested Hugh of Falkenberg with the principality of Galilee. He was seneschal of the kingdom, and next year was on his way south to join the king when the disaster of Ramleh took place on 17 May 1102. Hugh came up with eighty knights, and on arriving at Arsuf, 19 May, ${ }^{n}$ found the king, whom he accompanied to Jaffa two days later and assisted in the defeat of the Egyptians at the battle of Jaffa, on 27 May. ${ }^{23}$ Hugh was in Jerusalem during 1104,20 and was again with the king at another battle of Ramleh, on 27 August $1105 ; 30$ he attended the council of the barons held at that town early in $1106,{ }^{\text {n1 }}$ and in the spring of the same year built the castle of Toron, now Tibnin. ${ }^{32}$ This was to guard the northern march of the principality against Tyre, which was still in the hands of the Saracens. ${ }^{33}$ Hugh was killed in action in the Hauran, on August 1106, by Tugtakin of Damascus, and his brother Gerard died of his wounds eight days later at Nazareth. ${ }^{34}$ Hugh left two daughters, but they were so young that their claims to the fief were overlooked in the interests of the general safety of the kingdom, and in September 1106 the king invested his kinsman, Gervais of Bazoches, ${ }^{35}$ with the

11 Ibid. 495.

Ibid. 619.

- Ibid. 633 .

4 Ibid. 645-53, 656.

2. Röhricht, Qeschichte des Konigreicho Jerusalem, 70.

24 Hagenmeyer, Chron. 645. $\quad$ Ibid. 650.

" Rohricht, Regesta Rogni Hieraoolymitani, 43.

a W. B. Stevenson, The Crusaders in the East, 47.

" Röhricht, Geschichte des Konigreichs Jerusalem, 60.

* William of Tyre, Historia, xi. 5, in Migne, cci.

2 Tyre was taken on 17 July 1124.

24 Röhricht, Geschichte des Konigreichs Jerusalem, 61.

24 Prioux, Bull. de ka Soc. Arch. de Soisson, xix. 1865, 351-71. Gervais was son of Miles de Chàtillon, lord of Bazoches in Picardy, who died c. 1080 (cf. Schlum. berger, Renaud de Chditllon, 3, note on possible relationship between Gervais and Reginald of Chsitillon). Gervais probably went on the crusade in the train of Hugh of Vermandois in 1006. He had two brothers, one Hugh, who sucoeded his tather, 
principality. Gervais's reign was of short duration, as he was taken prisoner by the forces of Damascus under Tugtakin in May 1108. Hiв свptor, apparently presuming on the relationship of his prisoner with the king of Jerusalem, demanded the unheard-of ransom of Acre, Cayphas, and Tiberias for his release. Baldwin I offered 30,000 gold bezants and the exchange of five hundred Saracen prisoners, but could promise no more. Tugtakin declined this as insufficient, and gave Gervais the alternative of the Quran or the sword. The prince refused to apostatize and was thereupon beheaded. The Atabeg had his skull mounted as a drinking-cup. ${ }^{36}$

This brought the vacant principality into the king's hand, and a difficulty at once arises. In a charter of the abbey of Val Josaphat of the year 1109 a certain 'Willelmus Tyberiadentium princeps' appears. ${ }^{37}$ Röhricht, in a note, ${ }^{38}$ suggests 'de Buris', but this would clash with another charter ${ }^{30}$ wherein 'Balduini II regni anno III Willelmi de Buris anno I' are mentioned as coinciding for the date. The third year of Baldwin II was from 14 April 1120 until 13 April 1121, consequently William de Bures cannot have been prince in 1109. Now it is stated that in August 1108 the king, being at the time in the midst of preparations for the siege of Sidon, sent William, the son of Robert, duke of Normandy, in command of 200 horse and 500 foot to raid across Jordan..$^{\text {to }}$ The enterprise was wholly successful, and William brought a quantity of captives and plunder to Jerusalem. The force under William's command was large for those days, and more than the king would be likely to detach from his main array now gathering for the campaign against Sidon, particularly if it were to be placed under the command of a comparatively obscure knight. In these circumstances it is reasonable to suppose that it was this William who was invested with Galilee (under the conditions laid down by Tancred in 1102), and that his 700 men represent his levy ${ }^{41}$ as prince, together,

the other Gaucher, prior of St. Gemme in the diocese of Soiseons. Ibn el Athir, in Recweil des Historiens des Croioades, Historiens Orientaux, i. $268 \mathrm{calls} \mathrm{him} \mathrm{"}$ king's siater '; in this case either Gerberge or Ida de Bouillon must have married Milee. Guibert de Nogent (quoted by Prioux) says that the fief was taken from Gervais by the king, who almost immedistely restored it as the result of a feat of arms on the part of the prince. This seems unlikely, unless Gervais were only administrator in the king's name, and not actual prince; but this is not borne out by Rohricht, Regesta, 293, where he ranks as equal with Hugh I.

* Ibn el Athir, in Recueil, Hiotoriens Orientaux, i. 268 f.; Röhricht, Geschichte des Konigreichs Jerusalem, 73.

" Revue de TOrient Latin, vii. 114-15.

4 Röhricht, Regesta, additamentum, 56 a.

- Ibid. 97.

- Albert of Aix, $B$ istoria, x. 47.

a It is difficult to know exactly what the feudal levy of the principality was at this time, as there is no contempors ry record, both Ibelin (Famillies) and Sanudo being Inter in date. The carly principality included territories which subsequently became 
perhaps, with some small assistance from the king. At any rate that would supply a prince of the name of William in time to sign the charter above mentioned. Further, when Tancred and Baldwin du Bourg $*$ joined the king before Tripolis in April 1109, it was arranged that Tancred should recover Galile and the overlordship of Cayphes, ${ }^{\omega}$ giving up in exchange all claim to Edesse. The Latins took Tripolis on 12 July 1109,4 and William became possessed of house property therein. ${ }^{\text {s }}$ Shortly after the fall of Tripolis Tancred captured Tortosa (Antartus), and gave it to William. ${ }^{40}$ Tortosa was an important place in a rich district, and a port, and it may well have been granted to William as compensation for the loss of Galilee. William is last heard of as lord of Tortasa in the muster-roll of the vassals of Antiooh, when Tancred took the field against Aleppo in September 1111.7

It is uncertain whether Tancred went to Tiberias on the occasion of resuming the principality, and, as he was fully occupied with the affairs of Antioch, it does not seem that he revisited his southern dominions before he died, on 12 December 1112.8 In consequence, it is more than probable that the king had a certain

doteched from it, and the prince was overlord of Cayphes and Bessan, both of which are reckoned by Ibelin under other fiofs. The prince himself owed $100 \mathrm{knights}$, the fief of Toron 18, that of Basean 15, that of Cayphas 7, and the archbishop of Narareth 0in all 146 knights. The city of Tiberias owed 200 men-st-arms, the bishop of Tiberias 100, the archbiahop of Nazareth 150, the abbot of Mount Tabor 100, the lord of Cayphas 50, and the lord of Gerin 25-in all 625 men-at-arm. All these were owed to the ling, bot it is probable that in emergencies part at least were placed at the dispoesl of the prince, more perticularly when ho was constable or marehal of the kingdom, or when, as was often the case, the king was present in Galilee. Ibelin and Banudo do not agree as to the identity of all these figuree, and it is anlikely that the figures oven refer to the samo period, as it is more than doubtful that when Acre (which appears elsowhere in the lists) was importent enough to supply under varions headings 80 knights and no lese than 700 men-at-arms the principality of Gelileo could continue to supply its quots of $\mathbf{4 0}$ knights from the territories beyond Jordan. Moreover, many of the headings under Acre suggest that at the time referred to in the lists Acre was already the capital, i. e. after 1191, at which time Jerusalom could certainly not supply 500 men-at-arms, and tho prinoipality was practically non-existent.

- Baldwin da Bourg had boen released by Jawali in August 1108, and after fighting Tancred, who had been administering Edeasa, 18 September, he was defeated neer Turbeseal and fled to Tulupe, but ultimately recovered his county of Edessa : Sterenson, The Crueaders in the East, 85 notes.

4 Albert of Aix, Historia, xi. 12.

4 Ibn el Athir, in Recweih, Hitoriens Orientaux, 1. 274; Röhricht, Geschichte des Bonigreichs Jerwalem, 81.

4 Röhricht, Rogenta, 620.

“ A.1. 603, i. e. 31 July 1109 to 19 July 1110. Valenie, north of Tortosa, surrendered about 22 July 1109 , thus cutting of that town from the north: Btevenson, 86.

4 Albert of Aix, Hisforia, xi. 40. Willism was natural son of Robert of Normendy, born c. 1078-9, probably at Gerberoi, on the Norman border. He took the crosu after Tenchebray (2 September 1106): Dictionary of National Biography, art. 'Robert, Doke of Normandy'. In 1108 'Willelmus filius comitis' signs a royal chsirtor : Röhricht, Rogesta, 52. Albert, xi. 40, calls him 'Wilhelmus filius comitis Nortmanoram'. - Btovanson, 81, n. 3.

VOL. XXVII. - NO. OVII. 
amount of control over the fortunes of the principality during this period. Certainly he was at the head of an army at Tiberias in the beginning of $111^{40}$ and again in June 1113, when he was severely defeated by Maudud of Damascus. ${ }^{\text {so }}$ It is probable that it was at this time that the principality was given to Joscelyn of Courtenay, a fighting man of repute in the north who had been lord of Turbessel (Tell bashir) until recently, when, owing to a quarrel with his overlord, Baldwin du Bourg, count of Edessa, he had been deprived of that fief. ${ }^{51}$

Joscelyn attested a royal charter as prince in $1115^{, 28}$ and himself granted a manor to the abbey of Val Josaphat in February $1110^{* 3}$ as ' Goscelinus princeps Galilaese '. In May $1118^{\text {b4 Tiberias }}$ was ravaged by the Saracens, probably owing to Joscelyn's absence with the king on the raid into Egypt. Tugtakin and his forces retired about the end of July, and immediately Joscelyn raided the Hauran. He reached Bosra and wasted the country; he retook the castle of Hubais, and defeated the Damascenes under Buri. ${ }^{\text {ss }}$ Next year he repeated the raid with a small force, but having unwisely divided it was severely handled by the Beni Khalid on 30 March $1119 .{ }^{b 8}$ Later in the year Joscelyn seems to have made an unsuccessful attempt upon Ascalon, and afterwards went north by way of Tripolis ${ }^{37}$ to join in the campaign against

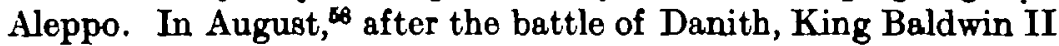
invested Joscelyn with his own former county of Edesse. Joscelyn thereupon relinquished Galilee into the king's hands. During the later years of his administration, since June $1115,{ }^{\infty}$ a certain knight, William de Bures, a Norman, witnessed his charters. This man may have been in Palestine as early as $1101,{ }^{61}$ and seems to have been wealthy, since he and his wife Agnes granted the manors of Jeraz and Soesme to the abbey of Val Josaphat in 1115. ${ }^{62}$ Apparently this wife died, and he married Eschiva I, daughter of Hugh of Falkenberg, the real heiress of the fief, as Tancred had no children and Joscelyn had voluntarily relinquished it.

William de Bures first appears as prince, William II, in 1120.0

- Sterenson, 60; Albert of Aix, Historia, xi. 36.

- Steveneon, 63.

"Ibid. 86; William of Tyre, Historia, xi. 22. Joscelyn was younger son of Joscelyn I of Courtenay by Elizs beth of Montlhery, sister of Melisende, countess of Rethel, who nas mother of Bald win du Bourg. He became lord of Turbessel c. 1101-2, and was taken prisoner with his cousin and overlord Baldwin in May 1104 (Ibn el Athir, in Recueil, Hishoriens Orientaux, i. 222 ; Röhricht, Oeschichte des Konigreichs Jerusalem, 50). He was released in August 1108.

" Röhricht, Regesta, 79. H Ibid. 87. Stevenson, 68-7.

4 Ibn el Athir, in Recueil, Historieno Orientaux, i. 315 ; Stevenson, 67, n. 3.

4 Albert of Aix, Hiotoria, xii. 31 ; Röhricht, Geschichte des Konigreiche Jerusalem, 129.

"Stevenson, 67; Fulchorius Carnotensis, Historia, iii. 2, in Migne, clv.

- Stevenson, 105, n. 4.

- Röhricht, Regesta, 79.

- Röbricht, Regesta, 80.

- Ibid. 106, n. 2.

a Ibid. addit. 36 a.

- Ibid. 01. 
By his first wife, Agnes, he had a son, Geoffrey, who stayed behind in Normandy. He also had a brother, Godfrey, who was killed on Joscelyn's ill-fated expedition into the Hauran in March 1110, and a sister who married Ralph de Ysis, and had three sons, Ralph, Simon, and William; of these William was a monk of the abbey of Val Josaphat, ${ }^{\text {et }}$ Simon a canon of the Holy Sepulchre, $\infty$ and Ralph, who was a layman in 1132, may have become a canon of Mount Sion. By his second wife William II was childless.

William II was a capable prince, as he was acknowledged to be by his contemporaries. He was constable of the kingdom $1123-41,77$ and was elected regent by the high court, and acted in that capacity during the latter part of the captivity of King Baldwin II, from 15 June to 29 August $1124 .^{\circ}$ He was present, and possibly, as regent and constable of the kingdom, commanded at the successful siege of Tyre, from 15 February to 7 July 1124. $\mathrm{He}$ attended the king at Acre in May $1105,{ }^{70}$ but left him during the end of the northern campaign of 1125- $\theta$, being apparently detached to guard Jaffa and the south, where he is found in January $1126,{ }^{71}$ some time before the king's return from the Hauran. Later in the year, however, he rejoined the court at Jerusalem. ${ }^{72}$ In October $1128{ }^{73}$ William II, accompanied by Guy Brisebarre, lord of Baruth (Beirut), ${ }^{74}$ was sent on an embassy to Fulk, count of Anjou, to ask him to marry Melisende, King Baldwin's only child, and heiress of the kingdom. He returned in April 1129, having been successful in his mission, and shortly afterwards went to Tiberias. ${ }^{75}$ In the autumn of 1136 William was with Fulk, now king of Jerusalem, at Naples," and next year accompanied him on the campaign against Zanki of Aleppo, who was attacking the border fortress of Mons Ferrandus in Tripolis. The king attempted to raise the siege, but was surprised on the march through the broken country in that district, and defeated. Raymond of Tripolis was captured, but the king and his people reached the castle, which lies on an isolated hill, and there they in their turn were besieged.7 The approsch of

4 Röhricht, Regesta, 131.

Ibid. 142.

a Ibid. 174.

- Ibid. 102 ; Albert of Aix, Historia, xii. 21.

- Stovenson, 114; Fulcherius Carnotengis, Historia, iii. 22. King Baldrin was captured by Nur ed daula Balak, nephew of Ilgari of Aleppo, near Karkar, 18 April 1123 (Stevenson, 109, n. 3). Ho was released by Timurtash, Igaxi's son, 29 August 1124. His ransom had been settled on 24 Juno 1124 as tho surrender of Erar (Stevenson, 111, n. 5) and 80,000 bezants (Röhricht, Geschichle des Konigreichs Jerusalem, 171, n. 1). On 6 September the king dishonourably declined to bo bound by his promise and refused to pay the ransom.

- Fulcherius Carnotensis, Historia, iii. $28 . \quad$ "* Röhricht, Regesta, 105.

"Ibid. 112-13. 72 Ibid. 116 .

" Röhricht, Geschichle des Königreichs Jerusalem, 185.

"Guy was brother of Walter I and father of Walter II. He was lord of Baruth from about 1127 to June 1153.

"Röhricht, Regesta, 127, 131.

"Ibid. 164.

"Ibn el Atbir, in Recueil, Historien Orientaux, 1. 481. 
Raymond of Antioch, however, induced Zanki to allow the garrison, who did not know that help was at hand, to march out with the honours of war and retire, together with the prisoners recently taken by the Saracens, into Tripolis. This was before 19 August $1137 .{ }^{78}$ In April 1140 William II received King Fulk at Tiberias, where there was a great gathering of the Latins. The king moved against Zanki in the Hauran, and after the enemy had retired (25 May) the Latins, in alliance with the Damascenes, took Banias, at the source of the Jordan, after a short siege in June 1140.70 William II is last heard of in February 1141, when he witnessed a charter at the king's palace in Naples. ${ }^{80}$ The exact date of his death is uncertain, but his nephew Elinard, who may perhaps be the same as the Helias who witnessed a charter in 1126 as 'heres feudi', 81 was already prince in 1142. He was Godfrey's son, and married Ermengarde d'Tbelin. ${ }^{83}$ Elinard went with Philip of Naples under Manasses d'Hierges, constable of the kingdom, to help Joscelyn II of Edessa. But the expedition was too late to prevent the capture of that city by Zanki, December 1144 to January 1145. Elinard was present at the great council of war held by the Emperor Conrad III near Acre, on 24 June 1148,8 and after the ignominious retreat from Damascus in the following August the prince of Galilee was suspected of having taken a bribe from the Saracens to use his influence against continuing the siege. One historian says that the 50,000 bezants which he is supposed to have taken were spurious. ${ }^{85}$

Elinard de Bures died leaving one daughter, afterwards Eschiva II, but she was too young to be married. After the death of Elinard, who last appears in August 1148, no evidence is available until 22 June $1150^{80}$ when one Simon appears as prince of Galilee. Du Cange suggests that he married Ermengarde d'Ibelin, widow of Elinard, and administered the fief on behalf of his infant step-daughter. ${ }^{87}$ Simon may perhaps have been the brother of William Tirell, marshal of Antioch, who witnessed as such in February 1149 and again in January $1167,{ }^{88}$ or Simon de Chattillon, who was a vassal of the barony of Caesarea, 1145-6.99 If this be so he may have been a relation of Gervais de Bazoches, who was of the Chattillon family, ${ }^{\infty}$ and have been given the fief

"Stevenson, 138.

"William of Tyre, I7. Q-10; Stevengon, 145.

* Röhricht, Regesta, 201. "Ibid. 115.

- Bhe was daughter of Balian I, third lord of Ramleh (d.c. 1154), and step-daughter of Hanassen d'Hierges. Her mother was daughter of Balduin, second lord of Ramleh and Mirabel. Her brother, Balian II, married the widow of King Amaury I.

- Ibn el Athir, in Recueil, Hiatorien Orientaux, i. 448; Rohricht, Geochichte des Konigreichs Jerusalem, 236.

4 Röhricht, Rogesta, 250.

H RXhricht, Geschichte des Kinigreichs Jerusalem, 205 ; Abul Faraj, 342.

4 Rohricht, Regesta, 268.

w Rohricht, Regerla, 253, 128.

"Du Cange-Rey, Les Familles d' Outrener, 447.

- See abovo, p. 47 n. 35. 
in virtue of this kinship. It is also possible that he was Simon de Ysis, nephew of William II, who was a canon of the Holy Sepulohre. This last supposition would not fit in with du Cange's suggestion that he married the ridowed Ermengarde. Simon was prince undoubtedly until 20 April $1154,{ }^{91}$ and as such was present at the siege of Ascalon, from January to August 1153..$^{92}$ Simon signs as Tiberiadensis, but after Guilelmus Tiberiadensis, in a charter of Baldwin III given at Acre $30 \mathrm{July} 1154$; and later in the same year Ermengarde, viscountess of Tiberias, grants land to the church of St. Lazarus with the consent of William, prince of Galilee. ${ }^{93}$ This William III was Elinard's younger brother, who now appears to take over the fief on behalf of his niece, perhaps after an absence in the west or on return from captivity among the Saracens. ' $W$ de Buris' grants land to the Hospital in Tiberias, on 28 October $1153^{, 4}$ by a charter which is witnessed by many of the chief men of the principality, but he does not style himself prince. But on 20 April of next year Simon still signs as Tiberiadensis with precedence over Philip of Naples, which seems to show that he signs as prince and not as a baron of the principality. Possibly William's claim to rule the fief for his niece was still before the high court. William III married Mary, sister of Walter III, lord of Baruth, ${ }^{25}$ who had himself married Agnes of Falkenberg, daughter of Hugh I. William had an only daughter, Eschiva, who married Hugh II, lord of Puy. ${ }^{90}$

Soon after September $1158^{\circ}$ William III either died or else handed over the principality to his niece, Eschiva II, as in Maroh $1159^{88}$ Walter of St. Omer was already husband of the princess and in her right prince of Galilee. He witnessed a charter on the thirteenth of that month describing himself as 'nuno dominus Tyberiadensis', from which it may be implied that at that date he was but newly raised to the dignity. Walter of Falkenberg, castellan of St. Omer 1145-57, was son of William II, castellan of St. Omer 1097-1126 and again 1128-43. It is more than likely that he was nephew of Hugh I of Falkenberg, prince of Galilee, who is called of St. Omer, ${ }^{90}$ and had a brother Gerard, who died at Nazareth in August 1106.100 Walter had

"1 Röhricht, Regesta, 291.

-3 Röhricht, Rogesta, 293, 204.

" William of Tyre, xvii. 21.

" lbid. 283.

* Walter III was son of Walter II, who died past March 1164. He was lord of Baruth 116z-6, lord of Blanchegarde 1168 to October 1179, and lord of Montreal May 1168 in right of his second wife, Helen de Milly. By his first wife he had a son and four daughters. Mary, the nidowed princess of Galilee, married Gerard de Ham, constable of Tripolis June 1199 to October 1217.

" Hugh II was son of Hugh I, constable of Tripolis 1161-3, and grandson of Walter the Penniless. He was lord of Puy October 1177-84, and by this marriage had ane danghter, Mary, who was twice married.

"Röhricht, Rogesa, 332

"Ibid. 336.

"A Annales, in Archives de TOrient Lation, li. $\mathbf{4 3 0}$

10 Röhricht, Geschichte des Konigreichs Jerusalem, 61. 
brothers, Gerard and Hugh. ${ }^{101}$ If this relationship be established it at once explains why Walter of St. Omer was given the hand of Eschiva II, heiress of Galilee, instead of some local baron. Eschiva II was daughter of Elinard, who was nephew by marriage to Eschiva I, daughter of Hugh I. But the disparity of age may not have been great. William II de Bures, husband of Eschiva I, had a son Geoffrey, who was born in Normandy and never came to Palestine. William's brother Godfrey, who was killed in 1119, was father of Elinard, who may well have been born at the beginning of the century. At any rate he was of full age in 1142, as no regenoy in his name is recorded for the principality, and he is found commanding his levy on an important expedition. He was probably of age in 1126 , when he and his brother sign a charter as 'heredes feudi', and had two cousins old enough to be priests..$^{102} \mathrm{He}$ was probably of the same generation as his aunt by marriage, Eschiva I; consequently his daughter, Eschiva II, was in fact only one generation junior to Walter. It may be assumed that she was born about 1143 , as she was still under age in September 1158 and married in March 1150. It is not unreasonable to suppose that Walter was born about 1116, soeing that his third brother was old enough to be a priest in 1142. This would make him forty-three at the time of his marriage, which took place on the occasion of his second pilgrimage to the Holy Land. ${ }^{103}$

There is record of five of Walter's children by this marriage : Hugh II, William, Ralph, Odo, and Eschiva. Of these Hugh and Ralph succeeded their parents, William is heard of no more after 1192, ${ }^{104}$ Eschiva married Eimery Rivet, seneschal of Cyprus (November 1197 to November 1210), ${ }^{106}$ and Odo became constable of Tripolis in January 1194 and retained the office until August $1196 .{ }^{106}$ After this he went with his brothers to Armenia, where he is found in December 1199.107 There he passed into the service of King Levon II and was given the lordship of Gogulat. In April $1216^{108}$ he was with Prince Raymond Rupin at Antioch, and is last heard of in July $1218^{100}$ at the court of Queen Alice of Cyprus. He left a daughter, Eschiva, who married Eimery Rivet, grandson of that other Eimery Rivet who had married her aunt. In 1261 sho disputed the title to the principality with her cousin, Eschiva III, daughter of Ralph. There were in all no less than six different ladies, daughters of the three reigning houses of the principality, all of whom were called Eschiva, three of them being princesses in their own right.

\footnotetext{
. 101 Giry, in Bibl. de I E cole des Chartes, 1874, 335-45.

in Röhricht, Regesta, 142.

in Röhricht, Regesta, 707.

in Potthast, i 809.

10s Ibid. 738, 848 .

100 Giry, ubi supra.

in Röhricht, Regesta, $880 . \quad$ in Ibid. 912.
} 
Walter had accompanied Dietrich, count of Flanders, on the second visit of the latter to Palestine. He was probably present at the siege of Damascus in July 1148, and served under the king as his paid man at the siege of Ascalon from January to August 1153. ${ }^{110} \mathrm{He}$ was with him at the siege of Blahasent (Bel hasem), a Saracen robber-castle in the hill-country above Sidon, on 16 March $1160,{ }^{111}$ and in Jerusalem at the end of November in the same year. ${ }^{118}$ Next year he was one of a great gathering of prelates and barons which met the king at Nazareth on $31 \mathrm{July}$ $1161,{ }^{113}$ after which he attended him at Acre on 21 November 1161, during what was his last visit there. ${ }^{114}$ He was with the king's successor, Amaury I, at Ascalon on 15 July 1164, ${ }^{115}$ and it is more than probable that he served through the second Egyptian campaign undertaken by that monarch from July to October 1164 . Next year he returned by way of Jerusalem, where he was on 7 April $1165,{ }^{116}$ to Tiberias at the end of that month. ${ }^{117} \mathrm{He}$ was with the court at Acre in April 1166 and May $1168,{ }^{118}$ and again at Jerusalem in August. ${ }^{110}$ In October 1168 Walter accompanied the king from Jernsalem, 11 October, ${ }^{120}$ to Ascalon, 20 October, ${ }^{121}$ and probably was with him during the third Egyptian campaign, from October 1168 to January 1169. In September $1169^{122}$ the prince of Galilee was again with the court at Acre, and had apparently returned to his principality by 1170.123

Walter died before the king in 1174, for his widow, the Princess Eschiva II, in a charter daled 'Amalrico I rego', 124 makes arrangements for masses to be said for the repose of the soul of her husband. The fact that her eldest son, Hugh, was still a minor, although of intelligent age, ${ }^{125}$ made it essential for Eschiva II to choose another consort. Raymond III, the celebrated count of Tripolis, had just been released from his ten years' captivity among the Saracens, ${ }^{120}$ and was now selected, either by the princess or by the high court, to administer the fief. Raymond, who was one of the ablest and best of the Syrian Latins, appears to have married about September 1174, and a month later was elected regent of Jerusalem by the king and the high court. He remained in Jerusslem until 13 December $1174,{ }^{187}$ when he went north to Tripolis to

110 William of Tyre, xvii. 21.

I1 Ibid. 355.

111 Roshricht, Regesta, 344.

11 Ibid. 368.

114 Ibid. 368. Baldwin III died at Beirut, 10 February 1162 : Stevenson, The Crusaders in the East, 184, n. 4.

111 Röhricht, Regesta, $400 . \quad$ "Ib Ibid. 413.

11 Ibid. addit. 422 \& ; Röhricht, Regesta, 449.

14 Ibid. 452.

121 Ibid. 453.

14 Mbid. 479 .

11 Ibid. 622.

117 Ibid. 414.

11" Ibid. 450.

14 Ibid. 487.

14 Ibid. 47.

is He hed been taken prisoner at Harim, 10 August 1164, by Nur ed din of Aleppo, and was released before May 1174.

wi Röhricht, Regena. 
send help against Saladin to Es salih of Aleppo, but, failing to conduct a vigorous campaign, made peace in May $1175 .{ }^{123}$ In the August of next year Raymond was engaged with Reginald of Chatillon in a raid on the Bika. ${ }^{120}$ In November, William of Montferrat, who had been invited to marry Sibyl, the heiresa presumptive of the kingdom, arrived, and Raymond laid down the regenoy in his favour. After this he returned to Tripolis, whence he engaged in the northern campaign, 20 November 1177, ${ }^{130}$ joining with Bohemond III of Antioch in the attack on Harim. This siege, however, had to be raised at the end of March 1178, on the arrival of roinforcements from Aleppo. ${ }^{131}$ In the spring of 1179 Raymond raided the Turkomans, and joined the king at Chastellet in February. ${ }^{132}$ In April, Baldwin IV ravaged the district of Banias and was defeated by Izz ed din, Saladin's nephew, on 10 April 1179. ${ }^{139}$ He retired on Tiberias, where Raymond was awaiting him, ${ }^{134}$ and remained there until May. Raymond and his two eldest step-sons accompanied the king when he marched up past Toron to Marj uyun, where Saladin defeated them disastrously on 10 June. ${ }^{135}$ After this, Raymond, who had with difficulty escaped with the king, retired to Tripolis, where he stayed until he rejoined the king at Jerusalem in Lent 1180 to arrange for peace with Saladin for the kingdom at Easter, 20 April, a policy which Raymond adopted for his county in June. ${ }^{130}$

On the death of William of Montferrat, count of Jaffa, Raymond was greatly opposed to the marriage of his widow to Guy of Lusignan, who had only his good looks to recommend him as a suitor. His opposition was overruled, and he fell into such disfavour that the king, persuaded by the Lusignan faction, actually forbade the prince to return from Tripolis to Galilee in the spring of $1182 . .^{177}$ A sort of reconciliation was, however, patched up, and the prince of Galilee joined the king on his mismanaged attack on Saladin's caravan and its convoy in the Oultrejourdain in the following June. ${ }^{138}$ This exposed Galilee to the Saracens, who at once raided the principality under Izz ed din. Raymond hurried north with the Latin army to Galilee, where there was much fighting during the summer. In February 1183 a great council of the barons was held at Jerusalem at which Rrymond was almost certainly present ; ${ }^{130}$ in March he was in Acre, ${ }^{100}$ and when Guy of Lugignan, the count of Jaffe,

12 William of Tyre, xxi. 8.

120 Behs ed din, in Recueil, Hishoriens Otientaux, iii. 63.

25 William of Tyre, Iri. 20.

213 Behs ed din, in Recueil, Historiens Orientaux, iii. 64.

12 Röhricht, Regerta, 672.

124 Röhricht, Regesta, 582.

12 William of Tyre, xxii. 1.

10 Rähricht, Rogesta, 622.

12 Willinm of Tyre, xri. 27.

145 Stovenson, 221 notes.

137 Ibid. 9.

120 Ibid. 15.

10 Ibidh 624. 
became regent for King Baldwin IV in August, Raymond joined him with his levy at Sepphoris. The Latin army was of unusual size, ${ }^{141}$ but the party quarrels of its leaders destroyed all chances of success, and the regent was unable to achieve anything of note. By remaining on the defensive, however, he compelled Saladin, whose army was suffering from lack of supplies, to retire in October without a decisive action. ${ }^{142}$ Next month the king dismissed Guy from the regency and resumed control of affairs. In December he set out on his last expedition, having as chief of his staff Raymond, who seems to have been responsible for the strategy of the campaign. ${ }^{123}$ The Latins successfully engaged Saladin in the Oultrejourdain, thereby raising the siege of Kerak, which had lasted less than a month. ${ }^{14}$

After this the king and Guy of Lusignan quarrelled openly, and the latter refused to admit him into his city of Ascalon. The king withdrew to Jaffa and thence to Acre, where he called a council of the barons in January 1184, and appointed Raymond to be regent for himself and his nephew, Baldwin the Boy, who had already been crowned on 20 November of the previous year. ${ }^{100}$ The regency was to last ten years. In the summer the Saracens again came up against Kerak in the Oultrejourdain on 13 August, and Raymond had to take steps for its relief. This was done on 3 September, but at the cost of exposing Galileo and Naples to a hostile raid which lasted a week. ${ }^{167}$ In March 1185 King Baldwin the Leper died, and was succeeded by King Baldwin the Boy with Raymond as regent, but on the death of the little king in August 1186 Guy of Lusignan, as husband of Sibyl, the heiress of the kingdom, seized the throne, in spite of the declaration of the high court in January 1184. Guy's cause was upheld by the patriarch and the grand masters, all of whom were likely to gain from the presence of a weak king upon the throne, and Raymond was deserted. He withdrew to Tiberias, where he remained until the fatal cam. paign of the next year. When his advice had been neglected and the king had lost all hope of safety, Raymond with his stepsons cut a way through the Saracens and fled to Tyre; thence he retired to Tripolis, where he died childless at the end of September 1187.148 $\mathrm{He}$ was succeeded in the principality by his step-son, Hugh II.

The Falkenberg was a fighting stock, and Hugh II and his

\footnotetext{
14 William of Tyre, xxii. 27, 1,300 knights and 15,000 infantry.

1a William of Tyre, $x \times$ ii. 27.

19 Röhricht, Geschichte des Konigreichs Jerusalem, 409.

14 Behs ed din, in Recueil, Historiens Orientaux, iii. 77.

is Röhricht, Geschichte des Konigreichs Jerusalem, 409.

14 Behs ed din, in Recueil, Historiess Orientaux, iii. 82.

14. Röhricht, Regesta, 662 .
} 
brothers were true to type. The two eldest boys distinguished themselves at the battle of Ascalon, 25 October 1177, ${ }^{10}$ and saw service again next year, when Hugh was taken prisoner bySaladin after the disaster of Marj uyun on 10 June 1179. Ransomed in September 1181, Hugh was again in the field against Saladin in July 1182, and in August was with his step-father in Acre. ${ }^{150}$ The date of his marriage is unknown, but his wife was Margaret of Ibelin, daughter of Balian II, lord of Ibelin, Naples, and Ramleh, and sister of John of Ibelin, the 'Vieux Sire de Baruth' of the next forty years. It must have been a difficult position for Hugh, a young man with a taste for war, eldest son of a princess suo iure, and step-son of a famous warrior who was administering his hereditary fief on his behalf. Hugh was well over fifteen, the age at which the assizes of Jerusalem allowed a boy to escape from the tutelage of his minority, but it appears that he did not succed as heir of his grandfather until after Raymond's death. It is possible that when Raymond became regent of the kingdom for the second time in $\mathbf{1 1 8 4}$ he may have ellowed Hugh at least to administer the principality. There is no actual charter granted by Hugh as such, but his high precedence among the barons of the kingdom when witnessing royal charters appears to indicate that he was more than heir apparent at the time. He was at Acre on 16 May $1186,{ }^{151}$ when he signs third among the barons. Hugh and his three brothers served with their step-father at the fatal battle of Hattin, $3 \mathrm{July} 1187$, and with him cut their way through the Moslem army before the fires were lit which choked what was left of the Latin forces into surrender with their smoke and heat. During and after this disastrous battle the Princess Eschiva II reappears, holding the castle of Tiberias, the town having been already taken. On Sunday, 5 July 1187 , it became known that there was no hope left for the Christians. The princess then capitulated upon terms and was allowed to retire freely from her castle.

The fugitives reached Tyre, where they bade farewell to their step-father, and on $13 \mathrm{July}$ they were joined by Conrad of Montferrat with a shipload of crusaders from the west. Gaining heart, some sort of a defence was arranged, and scattered Franks and stragglers who had escaped from the almost universal ruin came in, and under Conrad tho shattered kingdom found its rallying-point in Tyre. It would appear that Hugh II was second in command under Conrad, who may be considered as regent of the kingdom in Tyre. In October Hugh witnesses first among the barons, ${ }^{152}$ and in November, when the siege was set, distinguished himself greatly in the defence. In the great assault on the city, on 31 December, Hugh and his brother Odo themselves

\footnotetext{
"' Röhricht, Geschichle des Konigreichs Jerisalem, 378. in Röhricht, Regesta, 617.

w1 Ibid. 643 .

10 Röhricht, Regesta, 66.5-6.
} 
held the breach and beat back the stormers. ${ }^{163}$ This repulse led to the abandonment of the siege by Saladin on 2 January $1188 .{ }^{15}$ Shortly after the end of the siege, at some date not specified, Hugh II led an expedition from Tyre which raided Arsuf, captured the place, and released fifty Christian prisoners. It happened that the emir who had captured King Guy at the battle of Hattin was governor of the place, and he, together with some 500 of his men, was taken prisoner. No attempt was made to hold the town, but in July this emir was exchanged against William, marquess of Montferrat, father of Conrad, and grandfather of Baldwin the Boy, who also had been taken after Hattin. ${ }^{153}$ After this exploit Hugh II took part in the siege of Acre, where he is found on 19 November 1189.160 From the evidence of charters it is possible to gather that he continued there until 7 May 1191,157 and probably was present at the surrender on $12 \mathrm{July} .158$ Hugh II was entrusted by King Richard with the command of the rearguard on the auccessful march to Jafia, from 25 August to 10 September, ${ }^{160}$ during which took place the curious marching battle of Arsuf on 7 September.

When King Conrad died, on 28 April 1192, after a reign of three weeks, ${ }^{100}$ Hugh became the trusted adviser of Count Henry of Champagne, who succeded to the power and the wife, but not the title, of the king of Jerusalem. He was with him in Jaffa in January $1193,{ }^{161}$ and went to Acre the next month. ${ }^{162}$ On 5 January 1194 Hugh's brother Ralph first appears as seneschal of the kingdom, in succession to Joscelyn de Courtenay, Prince Joscelyn's grandson, who seems to have resigned the office. ${ }^{10}$ Both brothers appear to have been in either Tyre or Acre until the end of Richard's truce in 1106 . On Henry's death, 10 September $1197,{ }^{104}$ Hugh II was anxious that his brother Ralph should be chosen as his successor on the throne and in the affections of thrice-widowed Isabella I, the queen of Jerusalem. With the view of making this candidature more acceptable to the high court, the prince voluntarily abdicated from his claims to Galilee in favour of Ralph. The other suitor for the queen's hand was the king of Cyprus, Amaury of Lusignan, brother to King Guy now dead, and the high court rightly decided that it was more to the advantage of the continental kingdom that it should be united with the island monarchy, rather than

1 Röhricht, Aeschichte des Königreichs Jerusalem, 470, n. 1.

in Ibid. n. 8.

1:- Röhricht, Regesta, 683.

ic Stovenson, 269, n. 4.

1cs Ibid. 438, n. 6.

1 Ibid. 705.

1* Behs ed din, in Recueil, Historiens Orientaux, iii. 297.

11 Röhricht, Regesta, 709.

in Ibid. 710, 716 .

14 Ibid, 275-6 nn.

in Rohrtebt, Ueachichle des Konigreichs Jerusalem, 671, n. 3.

10 Ibid. 717 . 
be entrusted to the sword of a prince who had but a handful of territory left to him.

The new king was unfavourable to the Falkenberg brothers, and even accused Ralph of trying to murder him in 1198 . It would appear that there was not much in the charge, as the king never brought the accused to trial, but banished him from the realm at eight days' notice. ${ }^{165}$ The whole family seems to have gone north after this, and Ralph married Agnes, daughter of Reginald, who had been lord of Sidon and Beaufort, ${ }^{168}$ but now had to content himself with the dominion of the little town of Sarepta ; her mother, however, was an Ibelin, Héloïse, sister of the 'Vieux Sire'. They went up into Armenia in 1199, and when the Latins attacked Constantinople in $1204 \mathrm{Ralph}$ and his brother Hugh left Syria before 20 May of that year. ${ }^{107}$ Hugh died in Romania soon after this, and his widow, Margaret of Ibelin, married Walter III, lord of Caesarea. Ralph returned to Syria after the death of King Amaury, April 1205, and took part with Reynard of Nephin in his quarrel with Bohemond IV of Antioch and Tripolis in 1206 . Next year, $27 \mathrm{July} 1207,{ }^{108} \mathrm{Ralph}$ reappears at Acre as seneschal of the kingdom, in which cepacity he was present at the coronation of King John of Brienne, ${ }^{100}$ on 3 October 1210. He was with the court in July $1211^{170}$ and in January and August $1217,{ }^{171}$ but was absent from the great gathering of kings and princes, prelates, and barons, which took place in the October of that year. The prince of Galilee accompanied King John into Egypt, and served through the Damietta campaign, from August 1218 to March 1220.178 He is last heard of at Acre in May of this last year.

Ralph left one daughter, who married Odo of Montbeliard, who was constable of the kingdom and son of Walter of Montbeliard, a former constable of the kingdom and regent of Cyprus. ${ }^{173}$ Odo, in right of his wife, became entitled to what remained of the prinoipality, but this was not reconquered until after the treaties of February 1229 and June 1240. Odo was grandson of King Amaury, the former rival of Ralph, by his first marriage, and was one of the most important men in the kingdom. But he was important rather as constable, as regent, as a royal kinsman, than as prince of Galilee; and it is unnecessary todetail his exploits, which belong to the story of the kingdom at large and not to that

16 Du Cango-Rcy, Les Familles d Oudremer, 456.

14 Reginald was fourth lord of Sidon 1171-87, second lord of Beaufort 1171-02, first lord of Sa repta 1183-1200. He died befure 1204.

107 Röhricht, Geschichte des Kinigreichs Jerwoalem, 693.

14 Röhricht, Rejesta, 821.

iv Röhricht, Geschichte des Konigreichs Jerusalem, 701, n. 2.

170 Röhricht, Regesta, 853.

17 Ibid. 892, 898.

17 Ibid. 930.

1n Regent of Cyprus 1203-10. 
of the vanished principality. Let it suffice to record that Odo was regent of the kingdom January 1223 to July 1227, again from April 1228 toSeptember 1228, lieutenant-regent from February 1236 to April 1243, and co-regent with Balian I of Ibelin, lord of Baruth, and Philip de Montfort, lord of Tyre, from April 1243 to June 1243. He recovered Tiberias in June 1240, and is last heard of in Acre on 11 September 1244. ${ }^{174}$ Eschiva III, his fridow, enjoyed the principality but little longer; Tiberias itself was lost finally to Fakhr ed din at the head of an Egyptian army, 16 June 1247.175 Some portions of the fief were left, and in 1261 Eschiva, daughter of Odo of Falkenberg, lord of Gogulat, claimed the principality from Eschiva III, as being daughter of an elder brother to Ralph. This may have been true, but Odo had never been prince, while Hugh II had given the fief to Ralph for an express purpose, and had never reclaimed it. Besides, Odo should have disputed the title with Ralph in 1197, not left it for his daughter to raise the claim nearly seventy years later.

Eschiva III, the last sovereign princess, died after February 1265; ${ }^{176}$ leaving two daughters, Simone and Mary, who both married into the Ibelin family. Simone, being within the prohibited degrees with her husband, Philip of Ibelin, constable of Cyprus, had a dispensation from Pope Innocent IV to marry, ${ }^{177}$ and so brought the title of Galilee into that family. But no one held the principality again.

\section{H. Pirie-Gordon.}

11. Rohricht, Regesta, 1123.

1n The prinoipality hed been raided in July 1244 by Kharismisns : Btevenson, The Cruaders in the EaA, 323-1 nn.

11" Robrioht, Repesta, addit. 1336 a.

in Bull of 13 Angast 1253. 